4-volt types are used for A.c. mains operation; the 6.3. and 13-volt types are intended either for universal use on A.C. or D.C. mains, or for use with 6- and 12-volt motor-car batteries respectively. Fortunately, the number of valve bases is not yet equal to the number of valves, but fourteen different bases are listed, of which seven types are in common use in Great Britain, and the text explains that these seven may be connected up in 144 different ways. It is much to be regretted that those responsible for the design and manufacture of valves have not seen their way to bring about some measure of standardization; but in the chaos that exists, the valve data supplement referred to above should prove a useful guide.

\section{Co-ordination of Medical Services}

A DEPUTATION from the central emergency committee of the British Medical Association, including representatives of the Royal Colleges, was received on November 8 by Sir Thomas Inskip, the Minister for Co-ordination of Defence, who was accompanied by officers of the Government departments concerned. The deputation urged the establishment of machinery for the co-ordination of all medical services for the civilian population under a single body, and the coordination of civilian medical organizations under that of the Service Departments. It was also proposed that the machinery should be closely associated with the central emergency committee as being representative of all branches of the profession.

\section{A New Chemical Periodical}

A NEw periodical entitled Chemical Products and the Chemical News, which is being published monthly by Science Services, Ltd., 35 Great James Street, Bedford Row, London, W.C.2, is designed to emphasize the indivisibility of the chemical industry. It will accordingly deal with matters of interest to the chemical, drug, pharmaceutical and cosmetic industries, and particularly the new uses to which chemical products and related materials are being put and their future place in industry and in the framework of the modern world. In this policy, Chemical Products claims to be in the lineage of the Chemical News of Sir William Crookes. The first number (October) includes an article by Dr. E. R. Weidlein, director of the Mellon Institute, on industrial progress, in which developments in the fields of synthetic resins, lubricants and fuels, carbon black, plant stimulants, etc., in which that Institute has been concerned, are reviewed. In other articles A. L. Bacharach reviews the influence of laboratory on manufacturing technique, and C. W. D. Stafford describes the preparation and uses of liver extracts. Dr. W. Langer deals with the formulation of cosmetics, and Dr. C. I. B. Voge with that of mouth washes. An interesting account of the House of Roche is also included, together with the brief views of such eminent chemists as Prof. J. F. Thorpe, Dr. Joseph Needham and Dr. E. F. Armstrong on the nature, scope and policy of a chemical journal.

\section{Colonial Service: Recent Appointments}

THE following appointments have recently been made: F. J. Harper, agricultural officer, Nigeria; G. A. Jones, director of agriculture, Jamaica ; F. H. Fitch, geologist, Malaya; T. G. Chamberlain, veterinary officer, Kenya; D. Slavin, veterinary research officer, Kenya; J. F. C. Swan, veterinary officer, Northern Rhodesia; D. M. Hanschell, assistant botanist, British West Indies Central Sugar Cane Breeding Station, Barbados; W. A. Hughes, inspector of plants and produce, Gold Coast; J. Sheard, sleeping sickness control officer, Nigeria; O. T. Faulkner (director of agriculture, Malaya), principal, Imperial College of Tropical Agriculture, Trinidad (seconded); J. D. Gillespie (agricultural superintendent, British Guiana), agricultural officer, Sierra Leone; B. J. Hartley (district agricultural officer, Tanganyika Territory), agricultural officer, Aden; J. F. Ward (agricultural officer, Nigeria), agricultural officer, British Honduras; A. Cawley (engineering geologist), inspector of mines, Tanganyika Territory.

\section{Announcements}

Sir William BragG, president of the Royal Society, is to deliver an address on "The Advance of Science" at the Ely Diocesan Conference to be held at Cambridge on November 21.

Dr. H. Spencer Jones, Astronomer Royal, will deliver the fourteenth annual Norman Lockyer Lecture under the auspices of the British Association at the Goldsmiths' Hall, London, E.C.2, on Tuesday, December 6, at 4 p.m. The subject of the lecture will be "The Atmospheres of the Planets".

DR. HANS Holfelder, professor of general clinical roentgenology at Frankfort-on-Main, has been awarded the Albers-Schönberg Medal by the German Röntgen Society.

A series of open meetings on "National Defence" has been arranged by the Scientists' Group of the Left Book Club; the meetings are being held at the University Labour Club, 101 Great Russell Street, London, W.C.1, on Mondays at 8.15. Among the topics and speakers are: aerial warfare, by F. W. Meredith, food supplies in war time, by F. Le Gros Clark, the medical services, by Dr. D. Stark Murray and national defence and the scientific worker, by Prof. J. D. Bernal. Particulars can be obtained from the secretary of the Group, 175A Highbury New Park, London, N.5.

AcCording to a special health commission, Poland, which ought to have 25,000 medical practitioners, has only 12,000 , there being about $3 \cdot 7$ per 10,000 inhabitants. 61 per cent are settled in 28 towns which contain only 13.5 per cent of the total population. In order to provide medical attention in rural districts a law is being prepared to compel every medical practitioner to practise in the country for his first two years. 